\section{Impact of ICTs on Innovation Activities: Indication for selected European countries}

\author{
Jovana Zoroja \\ Faculty of Economics and Business, University of Zagreb, Croatia \\ jzoroja@efzg.hr
}

\section{Abstract}

The development and usage of information and communication technologies (ICTs) has particularly increased in the last two decades, while at the same time showing great potential to improve the efficacy of business processes, facilitate and drive innovations, and therefore increase competitiveness. Innovation activities represent an important factor for social and economic change as well as for increasing competitive advantages at both the national and firm levels. This paper focuses on the role that ICTs play in the innovation performance of selected European countries. Using data drawn from the Eurostat and Global Competitiveness Index (2007-2011) and panel regression analysis, research results indicate that ICTs have a significant impact on business innovation activities.

Key words: information and communication technology; innovation; business sophistication; competitiveness; European countries; regression analysis

\section{Introduction}

Information and communication technologies (ICTs) have played a key role in economic development and prosperity, especially in the last two decades (Campisi, De Nicola, Farhadi, \& Mancuso, 2013; Morgan Colebourne, \& Thomas, 2006). Further progress and adoption of ICTs are important factors in developing business strategies, encouraging creativity and innovation, and enhancing competitiveness (Ongori \& Migiro, 2010), which leads to a higher position in the globalized and competitive market.

A number of studies have shown the positive impact of ICTs on countries' economic and social development (Anon Higon, 2011; Campisi et al., 2013). In other words, the most developed and competitive countries lead in the usage and implementation of ICTs in terms of firms that invest significant funds in the implementation of ICTs as well as residents who use ICTs extensively (van Deursen \& van Dijk, 2010; Vu, 2011). Investments in ICTs are a crucial factor of economic and social growth, leading to higher innovation performance for individuals, firms, and countries. ICTs' development has a key role in personal, economic, and social development in relation to communication, business, learning, science, and government (Bocconi, Kampylis, \& Punie, 2013; Randver, 2006; Rogers, Takegami, \& Yin, 2001; Sharma \& Gupta, 2003; Zhu \& Kraemer, 2005).

Today innovation is considered one of the key factors of the knowledge-based economy, while the ability to innovate means creating and maintaining a sustainable
ORIGINAL SCIENTIFIC PAPER

RECEIVED: FEBRUARY 2016

REVISED: JUNE 2016

ACCEPTED: JULY 2016

DOI: 10.1515/ngoe-2016-0017

UDK: 659.2:004:001.895

JEL: C3, D8, 03

Citation: Zoroja, J. (2016). Impact of ICTS on Innovation Activities: Indication

for selected European countries.

Naše gospodarstvo/Our Economy, 62(3),

39-51. DOI: 10.1515/ngoe-2016-0017

\section{NG \\ OE}

NAŠE GOSPODARSTVO OUR ECONOMY

\begin{tabular}{l|l|l|l|} 
Vol. 62 & No. 3 & 2016 \\
\hline
\end{tabular}

pp. $39-51$ 
competitive advantage (Pejić Bach, 2014; Santos, Basso, \& Kimura, 2014). Adapting to fast changes and increased uncertainty of the turbulent global market while staying competitive indicates those firms ready to innovate their business processes, products, and services (Varis \& Littunen, 2010). A firm's future growth and success depend upon its ability to make continuous innovations. Thus, innovation issues are a key factor for social and economic changes and future prosperity (Santos et al., 2014; Zoroja, 2011).

In our research, we attempt to determine the relationship between ICTs and innovation in a group of countries that are geographically near, but substantially different according to the level of innovativeness and utilization of the digital technology. Therefore, we investigate how ICTs influence innovative activities of selected European countries in five areas: eLearning, personal usage of the Internet, eScience and high technology transfer, eCommerce, and eGovernment. We focus on European countries because of the diversity of the level of ICT usage and innovativeness among them, as indicated by several European Commission (EC) documents (e.g., EC, 2011; EC, 2010). In order to achieve this goal, a panel regression analysis model was used to estimate the relationship between ICTs and countries' innovation activity. Data were collected from the European statistical database, Eurostat (Eurostat, 2015), and the World Economic Forum (WEF) (2007-2011) for the five-year period of 2007 to 2011. Therefore, this paper will provide important insights into the impact that ICTs have on the innovation activity of the selected European countries.

The paper is structured in six sections. The first part of the paper, the introduction, provides brief and concise insights of the paper, including the goal and structure of the paper. The second part of the paper discusses the theoretical background, including ICTs, innovation, and the impact of ICTs on innovation activities as well as the development and usage of ICTs and different approaches to innovation. In the third section, methodology and data are defined. Results are presented in the fourth part of the paper. The major implications are discussed in the sixth section of the paper. Finally, the last section concludes the paper. The conclusion includes a summary of the research, comparisons with other research, practical implications and limitations, and future research.

\section{Theoretical background}

\subsection{ICTs as drivers of competitiveness}

ICTs have a strong influence on the society and economy. ICTs present an essential tool of competitiveness and growth for both firms and countries that are ready to use them and able to exploit them (Aguilera Enriquez, Cuevas-Vargas, \& Gonzalez Adame, 2015; Anon Higon, 2011). Due to their fast progress and development, ICTs are a support tool for managing business processes, building strategies, and boosting innovation and competitiveness. Therefore, firms and countries ready to use ICTs more rapidly than others have the ability to produce and deliver products and services of higher quality and lower costs, which leads to better performance and long-term profitability (Zoroja, 2015). In addition, these firms and countries are leaders on the market with growing competitive advantage.

ICTs are a key factor for socio-economic development in many countries, especially in business processes, communication, and education (Anon Higon, 2011; Vehovar \& Lesjak, 2007). A positive impact of ICT usage can be found in many other areas, including the financial sector, health organizations, education and science, and public organizations (Khalil, 2011). ICTs offer numerous benefits to different social issues, such as sustainable healthcare, security and privacy, carbon-free economy, and intelligent transport (Pavel, Fruth, \& Neacsu, 2015).

The implementation and usage of ICTs, especially the Internet, are growing every year. However, not everyone has the necessary knowledge and skills to use them. Therefore, it is important to educate young people on the appliance and advantages of ICT usage. In addition, educated employees with high levels of e-skills are a crucial factor for competitiveness, growth, and employment (van Deursen \& van Dijk, 2010). Another positive consequence is the reduction of the digital divide between countries.

The implementation of ICTs leads to higher overall competitiveness (Puzova \& Maresova, 2014). According to the European Commission (2010), ICTs drive $20 \%$ of productivity growth in the European Union countries. The usage and adoption of ICTs increase the development of employees' e-skills, improve business processes and quality of products/ services, encourages employment, and strengthens relationships with customers and partners (Haseeb, 2015). However, firms and countries that are not ready to use and at the same time invest in ICTs lag behind, leading to higher discrepancies between developed and developing countries (Singh, 2012). In other words, developing firms and countries are those not able to exploit the benefits of ICTs, which leads to higher social and economic development (Vu, 2011).

\subsection{Innovation}

Innovation can be defined as the adoption of a new idea that enables organizations to sustain a competitive advantage (Grolleau et al., 2013). Thus, innovation refers to the 
creative process resulting in new and unique products, services, or production processes (Arias-Aranda et al., 2001). In other words, innovation refers to three different forms: product/service, process, and business system (Wagner \& Hansen, 2005). Innovation processes’ implicit interactions include the generation, adoption, implementation, and incorporation of new and unique ideas and behaviors (Yam et al., 2011).

Innovations are a key factor to social and economic change, which imply new product-market-technology-organization combination (Lopes Santos et al., 2014; Wagner \& Hansen, 2005). Innovation can be classified into two types: radical and incremental (Lopes Santos et al., 2014; Schumpeter, 1934). Characteristics of incremental innovation include using existing ICTs, having low uncertainty, improving competitiveness within the current market. The characteristics of radical innovation are exploring new ICTs, generating high uncertainty, and creating dramatic change in order to transform the market's existing situation. Another classification of innovation refers to technological and administrative factors (Damanpour, 2001). Technological innovations imply new processes, products, or services while administrative innovations imply new procedures, policies, and organizational forms. In our work, we focus on the measurement of innovativeness using the Global Competitiveness Framework as a proxy for innovativeness in European countries, with a focus on the innovation and sophistication factor subindex,

Table 1. Global Competitiveness Index: Innovation and Sophistication Factors Subindex

\begin{tabular}{|c|c|c|c|}
\hline \multicolumn{4}{|c|}{ INNOVATION AND SOPHISTICATION FACTORS } \\
\hline \multicolumn{2}{|c|}{$\begin{array}{l}11^{\text {th }} \text { pillar: Business } \\
\text { sophistication }\end{array}$} & \multicolumn{2}{|c|}{$12^{\text {th }}$ pillar: Innovation } \\
\hline 11.01 & $\begin{array}{l}\text { Local supplier } \\
\text { quantity }\end{array}$ & 12.01 & $\begin{array}{l}\text { Capacity for } \\
\text { innovation }\end{array}$ \\
\hline 11.02 & Local supplier quality & 12.02 & $\begin{array}{l}\text { Quality of scientific } \\
\text { research institutions }\end{array}$ \\
\hline 11.03 & $\begin{array}{l}\text { State of cluster } \\
\text { development }\end{array}$ & 12.03 & $\begin{array}{l}\text { Company spending on } \\
R \& D\end{array}$ \\
\hline 11.04 & $\begin{array}{l}\text { Nature of competitive } \\
\text { advantage }\end{array}$ & 12.04 & $\begin{array}{l}\text { University-industry } \\
\text { collaboration in R\&D }\end{array}$ \\
\hline 11.05 & Value chain breadth & 12.05 & $\begin{array}{l}\text { Gov't procurement } \\
\text { of advanced tech } \\
\text { products }\end{array}$ \\
\hline 11.06 & $\begin{array}{l}\text { Control of } \\
\text { international } \\
\text { distribution }\end{array}$ & 12.06 & $\begin{array}{l}\text { Availability of } \\
\text { scientists and } \\
\text { engineers }\end{array}$ \\
\hline 11.07 & $\begin{array}{l}\text { Production process } \\
\text { sophistication }\end{array}$ & 12.07 & $\begin{array}{l}\text { Utility patents per } \\
\text { million population }\end{array}$ \\
\hline 11.08 & Extent of marketing & & \\
\hline 11.09 & $\begin{array}{l}\text { Willingness to } \\
\text { delegate authority }\end{array}$ & & \\
\hline
\end{tabular}

Source: WEF (2010-2011) 11th pillar: business sophistication, and 12th pillar: innovation. Table 1 presents the indicators that serve as the basis for the forming the innovativeness measurement. The innovation and sophistication factor subindex refers mostly to the improvement of the business using innovative strategies and products. GCI 11th pillar: business sophistication refers to the quality of a country's business networks and of firms' business processes that lead to higher innovative performance and efficiency as well as increased productivity and could be considered the administrative innovations. The 12th pillar: innovation refers mostly to the technological innovations (e.g., availability of scientists and engineers) important for countries' socio-economic progress. In addition, based on the description of the indicators used in Table 1, it can be concluded that both incremental and radical innovations are measured. For example, patents can be an indicator of both radical and incremental innovations.

In today's turbulent and globalized world, innovation activities are becoming a crucial need and no longer an option (Arias-Aranda et al., 2001). Innovations are a critical factor to a firm's competitive advantage. In addition, benefits of continuous innovations to a company lead to a better understanding of customer needs, satisfied clients, and a leading position on the market (Wagner \& Hansen, 2005).

\subsection{Impact of ICTs on Innovation}

The development of ICTs provides higher efficiency gains as well as a higher level of innovation activity. Innovations present a new way of organizing business that can be significantly improved by ICTs usage (Haseeb, 2015). Therefore, the most developed and innovative organizations are those developing and using ICTs to facilitate and drive innovations in business processes and in products and services (Arvanitis, Loukis, \& Diamantopoulou, 2013). Up-to-date progress in ICTs offers great opportunities for organizations' research and development $(\mathrm{R} \& \mathrm{D})$ activities, which lead to higher innovation performance (Kleis, Chwelos, Ramirez, \& Cockburn, 2012). In other words, science and technology refer to driving forces for innovation activities (Hjalager, 2010).

Literature reviews regarding the relationship between ICTs and innovation are limited. Few studies have analyzed the influence of ICTs on innovation performance of the firms or countries. Koellinger (2008) found that e-business technologies foster innovation, especially in internal processes and in offering new products on the data of European firms. In her research, Anon Higon (2011) tried to provide new empirical insights into the role of ICT usage in the innovation activities of UK SMEs. Research has shown that the impact of ICTs depends on the ICTs' application, innovation performance, 
and firm characteristics. Arvanitis et al. (2013) found that hard and soft ICT capital has a strong influence on firms' processes, product, and service innovation

The best examples of the most developed and competitive countries in the world are Finland, Sweden, and Singapore, which are the top three best-performing countries according to the Network Readiness Index for the last five years (i.e., 2011-2015) (WEF, 2011-2015; Yunis, Koong, Liu, Kwan, \& Tsang, 2012). The Global Information Technology Report presented the progress and influence of ICTs to social and economic development worldwide through Network Readiness Index. The three mentioned countries (Finland, Sweden, and Singapore) are also leaders in the field of innovation activities. Finland and Sweden are in the top 10 and Singapore in the top 13 countries according to GCI subindex-innovation and sophistication factor subindex in the last five years (WEF, 2011-2015). Every year their position is getting better, and it is expected to improve their rank in the future regarding innovation activities.

\subsection{Developing the Framework for the Assessment of ICTs' Impact on Innovation}

ICTs can be used in many different areas, such as education, business, health, private issues, science and technology, and public services (Blackman, 2004; Zott, 2000). Therefore, we selected the five main areas of ICT usage for the analysis: eLearning, Internet usage, eBusiness, eScience and technology transfer, and eGovernment. Based on the relationship of ICT usage in society and innovativeness, using the Global Competitiveness framework, the research model shown in Figure 1 was developed.

\section{Impact of e-learning on innovations in society}

The progress of ICTs and its usage have a strong impact on the development of individuals, companies, and countries (Pejic Bach, 2014). The usage of ICTs in education has improved learning and teaching processes and has led to a virtual learning environment. It is especially important to mention e-learning and its significant advantages in academic or business education. There are several benefits of e-learning, especially for employees, such as no need to travel, time and financial reduction, interaction among employees from different countries/continents, and the faster exchange of experience and ideas (Pena Seixas, Bostock, \& Eleftheriou, 2012.). This argumentation leads us to the development of the first hypothesis:

H1: The increase of eLearning usage has a positive influence on innovation activities.

Impact of personal Internet usage on innovations in society

The Internet was first used for communication, but today it is used for social interaction, education, business, and numerous other activities of individuals. Using the Internet, individuals can pay their bills, buy different products or services, organize trips, or find jobs (Hasim \& Salman, 2010). Although there are still disparities among countries regarding Internet usage, the Internet is increasingly becoming available to a larger number of people (Haythornthwaite \& Wellman, 2002). Therefore, it is possible to use the Internet to foster innovation activities in society, especially regarding employment opportunities, banking services, and shopping (Chatzoglou \& Vraimaki, 2010).

Figure 1. Research model

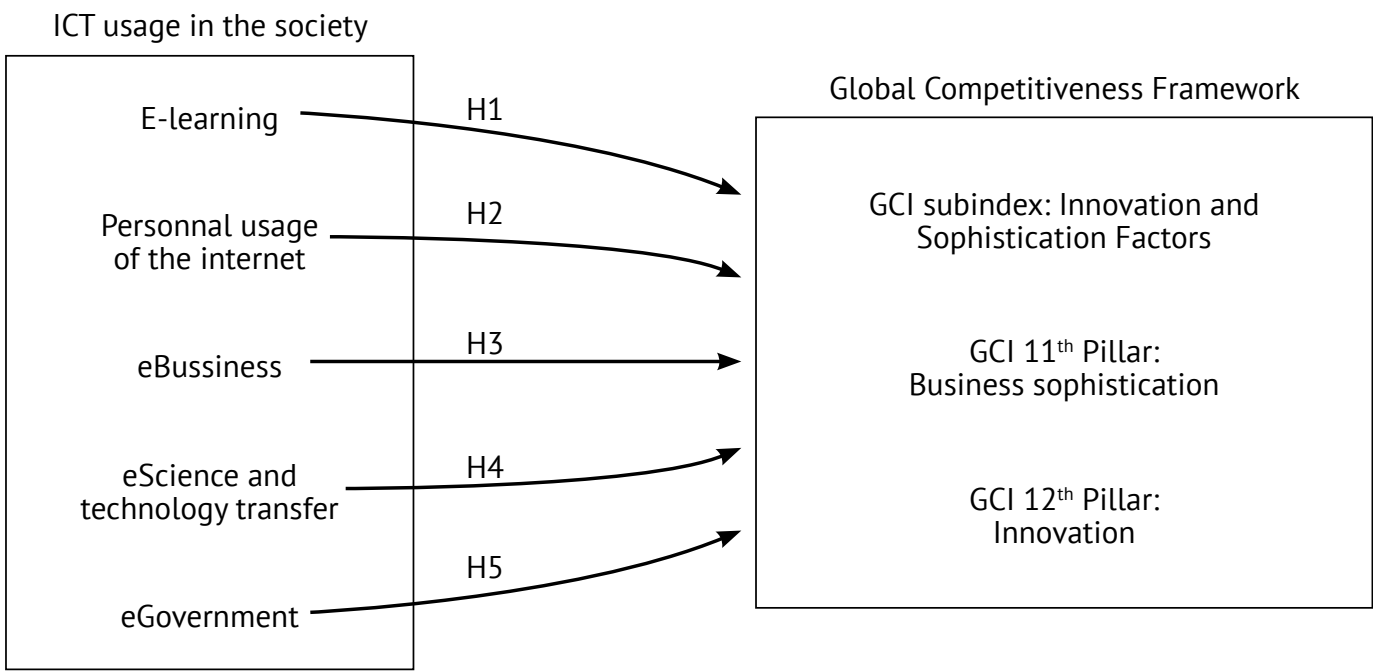


This discussion leads us to the development of the second hypothesis:

H2: The increase of personal Internet usage has a positive influence on innovation activities.

\section{Impact of eBusiness usage on innovations in society}

ICTs' usage provides several benefits to firms, such as higher competitiveness and management effectiveness, lower costs, and better business performance (Jones, Beynon-Davies, \& Muir, 2003). The Internet presents the main source for communication, learning, business, job exchange, and the buying or selling of products and services (Sharma \& Gupta, 2003) and represents one of the basic determinants of business efficiency increases (Damanpour, 2001). Firms that foster ICT usage are known for their strong innovation activity (Berman \& Hagan, 2006). eBusiness provides several benefits to firms, including quality and strategic improvements, time and cost savings, and access to new markets (Jones et al., 2003), which leads to innovations in business processes and strategies and raises the needs for the development of the third hypothesis:

\section{H3: The increase of eBusiness usage has a positive influence on innovation activities.}

\section{Impact of eScience and technology transfer on innovations in society}

eScience and technology transfer present the exchange of knowledge, ideas, and information that have a positive impact on competitiveness and business innovation (Landry, Amara, Cloutier, \& Halilem, 2013). Technology transfer presents a valuable source of innovation, which ensures firms' higher levels of performance and better position on the global market (Sexton \& Barrett, 2004). Therefore, countries and firms are trying to take part in eScience and technology transfer. Such argumentation leads us to the development of the fourth hypothesis:

H4: The increase of eScience and technology transfer usage has a positive influence on innovation activities.

\section{Impact of eGovernment on innovations in society}

The usage of ICTs is significantly changing the lives of people, and public administration has to follow these trends in order to increase the quality of their services to citizens. ICT usage and development in public administration institutions lead to higher transparency and efficiency of their services
(Ndou, 2004). eGovernment services offer several benefits to citizens, such as increased accessibility of public services and information, strengthened democracy, higher efficiency of public activities, and better and faster communication (Carter \& Belanger, 2005). Therefore, more and more countries are trying to improve their public administration services and invest more in their further development. This analysis leads to the development of the fifth research hypothesis:

H5: The increase of eGovernment usage has a positive influence on innovation activities.

\section{Methodology and Data}

\subsection{Empirical Research}

The goal of this paper is to analyze the influence of ICT usage on innovation performance of selected European countries. In order to achieve this goal, a panel regression analysis model was used. The panel regression analysis presents a statistical method using two and " $n$ " dimensional panel data. The data are usually collected over time for the same group of units, and a regression is run over these two dimensions. Panel regression provides an evaluation of the influence of independent variables to the dependent variables over the time. Therefore, we can analyze the change in innovation performance as a result of ICT usage over a five-year period (i.e., 2007-2011).

\subsection{Data Description}

Data on ICT usage and innovation performance for 32 European countries were collected from 2007 to 2011. In addition to the 28 European Union countries, data were collected for Iceland, Norway, Macedonia, and Turkey. Other European countries were not used in the analysis due to missing data for selected variables and for selected years. Data were collected from the European statistical database (Eurostat, 2015) and from the Global Competitiveness Report (WEF, 2007-2011).

\section{Independent variables}

Data on ICT usage have been collected for 17 variables from Eurostat (Eurostat, 2015) and are used as independent variables. Eight of the 17 variables refer to the ICT usage of individuals aged 16 to 74 (eLearning, Internet usage, and eGovernment). The other nine variables refer to companies' ICT usage (eBusiness, eScience, and technology transfer) with at least 10 employees. Data are shown in percentages. 
The area of eLearning was analyzed using four variables: (i) eLRN1: purchase of materials for e-learning (percentage of individuals 16-74), (ii) eLRN2: search for information on education and training (percentage of individuals 16-74), (iii) eLRN3: use of the Internet for education and training (percentage of individuals 16-74), and (iv) eLRN4: use of the Internet for decision-making on learning (percentage of individuals 16-74).

Variables referring to personal Internet usage are: (i) IntUSG1: use of online banking (percentage of individuals 16-74) and (ii) IntUSG2: use of the Internet for finding an employment (percentage of individuals 16-74). Variables related to the area of e-Government are: (i) eGOV1: using public administration sites to send forms (percentage of individuals 16-74) and (ii) eGOV2: communication with public departments (percentage of individuals 16-74).

The selected variables referring to the area of eBusiness are: (i) eBUS1: CRM software usage (percentage of firms with 10+ employees), (ii) eBUS2: Internet purchase (percentage of firms with 10+ employees), and (iii) eBUS3: ordering via Internet (percentage of firms with 10+ employees).

The selected variables related to the area of eScience and technology transfer are: (i) eSCNtechTR1: high-technology import within EU27 (percentage of firms with 10+ employees), (ii) eSCNtechTR2: high-technology import outside EU27 (percentage of firms with 10+ employees), (iii) eSCNtechTR3: high-technology import in the world (percentage of firms with 10+ employees), (iv) eSCNtechTR4: high-technology export within EU27 (percentage of firms with 10+ employees), (v) eSCNtechTR5: high-technology export outside EU27 (percentage of firms with 10+ employees), and (vi) eSCNtechTR6: high-technology export in the world (percentage of firms with 10+ employees).

\section{Dependent variables}

Data on innovation performance were collected from WEF (2007-2011), which measures competitiveness of 142 countries all over the world and presents the Global Competitiveness Index (GCI). The GCI is composed of three subindices (efficiency enhancers, basic requirements, and innovation and sophistication factor). In our research, a country's innovation performance is used as the dependent variable for the 32 European countries in the five-year period (2007-2011). In other words, data for the innovation and sophistication factor subindex and its two pillars, business sophistication and innovation, which are part of GCI, are used as the dependent variables.

\section{Results}

The goal of the paper was to evaluate the impact that ICTs have on countries' innovation activities. Using data drawn from the Eurostat and GCI (2007-2011), we conducted a panel regression analysis that showed that ICTs have a significant influence on innovation performance of the selected European countries.

Table 2. Panel Regression Analysis Results

\begin{tabular}{|c|c|c|c|}
\hline \multirow{2}{*}{$\begin{array}{l}\text { ICT usage } \\
\text { in the society }\end{array}$} & \multirow{2}{*}{$\begin{array}{c}\text { GCl subindex } \\
\text { Innovation and } \\
\text { Sophistication } \\
\text { Factors }\end{array}$} & \multicolumn{2}{|c|}{$\mathrm{GCl} 11^{\text {th }}$ and $12^{\text {th }}$ pillars } \\
\hline & & $\begin{array}{c}\text { Business } \\
\text { sophistication }\end{array}$ & Innovation \\
\hline Intercept & $3.046^{* * *}$ & $3.626^{* * *}$ & $2.563^{* * *}$ \\
\hline \multicolumn{4}{|c|}{ eLearning } \\
\hline eLRN1 & $0.026^{* * *}$ & $0.024^{* * *}$ & $0.030^{* * *}$ \\
\hline eLRN2 & -0.008 & $-0.012^{* * *}$ & -0.004 \\
\hline eLRN3 & 0.019 & $0.022^{* *}$ & 0.012 \\
\hline eLRN4 & -0.014 & $-0.017^{* *}$ & -0.009 \\
\hline \multicolumn{4}{|c|}{ Personal usage of the Internet } \\
\hline IntUSG1 & $0.009^{* * *}$ & $0.008^{* *}$ & $0.011^{* * *}$ \\
\hline IntUSG2 & $-0.016^{* *}$ & $-0.020^{* * *}$ & -0.009 \\
\hline \multicolumn{4}{|c|}{ eBusiness } \\
\hline eBUS1 & 0.008 & 0.008 & 0.006 \\
\hline eBUS2 & $0.016^{* * *}$ & $0.017^{* * *}$ & $0.013^{* * *}$ \\
\hline eBUS3 & $-0.011^{* *}$ & -0.008 & -0.008 \\
\hline \multicolumn{4}{|c|}{ eScience and technology transfer } \\
\hline eSCNtechTR1 & -0.001 & -0.009 & -0.002 \\
\hline eSCNtechTR2 & $-0.027^{* * *}$ & $-0.024^{* * *}$ & $-0.027^{* * *}$ \\
\hline eSCNtechTR3 & 0.040 & 0.043 & 0.041 \\
\hline eSCNtechTR4 & 0.035 & 0.001 & $0.054^{* *}$ \\
\hline eSCNtechTR5 & 0.017 & 0.001 & $0.025^{* *}$ \\
\hline eSCNtechTR6 & -0.032 & 0.009 & -0.055 \\
\hline \multicolumn{4}{|c|}{ eGovernment } \\
\hline eGOV1 & -0.005 & -0.008 & -0.002 \\
\hline eGOV2 & 0.007 & $0.009^{* *}$ & 0.004 \\
\hline \multicolumn{4}{|c|}{ Model validation } \\
\hline $\mathrm{R}^{2}$ & 0.790 & 0.758 & 0.770 \\
\hline Adjusted $\mathrm{R}^{2}$ & 0.765 & 0.729 & 0.742 \\
\hline \multicolumn{4}{|c|}{$\%$ of statistically significant variables } \\
\hline $\begin{array}{l}17 \text { variables } \\
(100 \%)\end{array}$ & $35 \%$ & $53 \%$ & $35 \%$ \\
\hline
\end{tabular}

Note: $* * *$ statistically significant at $1 \%$, ** statistically significant at $5 \%$; $\mathrm{R}^{2}$ is coefficient of determination; Adjusted $\mathrm{R}^{2}$ is adjusted coefficient of determination

Source: Authors' survey based on data from Eurostat (2007-2011) and WEF (2007-2011) 
Table 2 presents the regression coefficients and goodness of fit for all regression models. Three dependent variables are shown in the header: GCI subindex-innovation and sophistication factor subindex, GCI $11^{\text {th }}$ pillar: business sophistication, and GCI $12^{\text {th }}$ pillar: innovation. Seventeen independent variables of ICT usage by individuals and enterprises are divided into five areas (eLearning, Internet usage, eBusiness, eScience and technology transfer, and eGovernment) and are shown in the first column.

Most of the independent variables influenced the GCI $11^{\text {th }}$ pillar: business sophistication (53\%). All variables regarding eLearning and Internet usage by individuals influenced the GCI $11^{\text {th }}$ pillar: business sophistication while, from the other three ICT areas, at least one variable influenced GCI $11^{\text {th }}$ pillar. Approximately one-third of the 17 independent variables (35\%) affected the two other dependent variables GCI subindex-innovation and sophistication factor subindex and GCI $12^{\text {th }}$ pillar: innovation. Coefficients of determination range from 0.758 to 0.790 . The adjusted value of coefficients of determination (adjusted $\mathrm{R}^{2}$ ) is a bit lower and ranges from 0.729 to 0.765 . It can be concluded that both measures indicate adequate goodness of fit for all of the regression models. Further discussion of the results presented in Table 2 will be presented in the rest of the paper.

\section{Discussion}

Tables 3 through 7 present the relationships among individual independent variables referring to the five areas of ICT usage (eLearning, Internet usage, eBusiness, eScience and technology transfer, and eGovernment) and dependent variables (GCI subindex-innovation and sophistication factor subindex, GCI $11^{\text {th }}$ pillar: business sophistication, and GCI $12^{\text {th }}$ pillar: innovation). In order to present the level of statistical significance, we used thresholds of $1 \%$ and $5 \%$, with the significance in parentheses, which represents the positive or negative sign of the regression coefficient.

\section{H1: The increase of eLearning usage has a positive influ- ence on innovation activities.}

Table 3 presents the relationship between individual independent variable eLearning (eLRN) and dependent variables GCI subindex-innovation and sophistication factor subindex, GCI $11^{\text {th }}$ pillar: business sophistication and GCI $12^{\text {th }}$ pillar: innovation. The independent variable eLearning is presented through four areas: eLRN1: purchase of materials for e-learning, eLRN2: search for information on education and training, eLRN3: use of the Internet for education and training, and eLRN4: use of the Internet for decision-making on learning.
Table 3. Level of Statistical Significance of Independent Variable eLearning (eLRN)

\begin{tabular}{lccc} 
ICTs & GCl subindex & $\mathrm{GCl} 11^{\text {th }}$ and $12^{\text {th }}$ pillars \\
\cline { 2 - 4 } variables & $\begin{array}{c}\text { Innovation and } \\
\text { Sophistication } \\
\text { Factors }\end{array}$ & $\begin{array}{c}\text { Business } \\
\text { sophistication }\end{array}$ & Innovation \\
\hline eLRN1 & $1 \%(+)$ & $1 \%(+)$ & $1 \%(+)$ \\
\hline eLRN2 & $1 \%(-)$ & \\
\hline eLRN3 & & $5 \%(+)$ & \\
\hline eLRN4 & $5 \%(-)$ & \\
\hline
\end{tabular}

Source: Authors' survey based on data from Eurostat (2007-2011) and WEF (2007-2011)

A positive relationship exists between all innovation indices (GCI subindex-innovation and sophistication factor subindex, GCI $11^{\text {th }}$ pillar: business sophistication, and GCI $12^{\text {th }}$ pillar: innovation) and the eLearning indicator, which refers to buying materials via the Internet (eLRN1: purchase of materials for e-learning). A positive relationship also exists between the GCI $11^{\text {th }}$ pillar: business sophistication and eLearning indicator, which refers to the use of the Internet for education (eLRN3: use of the Internet for education and training). A negative relationship between GCI $11^{\text {th }}$ pillar: business sophistication and two eLearning indicators measured the passive usage of eLearning tools (eLRN2: search for information on education and training and eLRN4: use of the Internet for decision-making on learning). Passive usage of eLearning regarding the search for information and decision making could explain the negative relationship between the GCI $11^{\text {th }}$ pillar: business sophistication and the two eLearning indicators. Based on the results, it could be concluded that the use of eLearning has a positive influence on a country's innovation activities. In other words, the first hypothesis (H1) of this paper has been confirmed.

In today's information society, people use ICTs every day for education and training while ICTs enable and support the collaboration between students and professors (Cross, 2004; Wan, Wang, \& Haggerty, 2008). However, the development and usage of eLearning in developing countries are still lagging compared to the eLearning market in developed countries. Therefore, there is great potential for using eLearning in developing countries. The active usage of eLearning, by buying materials for e-learning and using the Internet for education and training, encourages an innovation approach in learning and teaching processes, which leads to higher competitiveness of educational systems. E-learning improves and innovates education because it provides the rapid exchange of knowledge and information, offers lifelong learning, and facilitates learning among students from different countries (Bocconi et al., 2013). Therefore, the most popular and most successful universities, as well 
as the most successful companies, are those using ICTs to offer new and unique learning processes to their students or employees (Bell, 2007; Zhang \& Nunamaker, 2003).

H2: The increase of Internet usage has a positive influence on innovation activities.

Table 4 presents the relationship between the individual independent variable of Internet usage by individuals (IntUSG) and the dependent variables GCI subindex-innovation and sophistication factor subindex, GCI $11^{\text {th }}$ pillar: business sophistication, and GCI $12^{\text {th }}$ pillar: innovation. The independent variable Internet usage is presented through two areas: IntUSG1: use of online banking and IntUSG2: use of the Internet for finding an employment.

Table 4. Level of Statistical Significance of Independent Variable Internet Usage (IntUSG)

\begin{tabular}{lccc} 
ICTS & GCl subindex & $\mathrm{GCl} 11^{\text {th }}$ and $12^{\text {th }}$ pillars \\
\cline { 2 - 4 } variables & $\begin{array}{c}\text { Innovation and } \\
\text { Sophistication } \\
\text { Factors }\end{array}$ & $\begin{array}{c}\text { Business } \\
\text { sophistication }\end{array}$ & Innovation \\
\hline IntUSG1 & $1 \%(+)$ & $5 \%(+)$ & $1 \%(+)$ \\
\hline IntUSG2 & $5 \%(-)$ & $1 \%(-)$ & \\
\hline
\end{tabular}

Source: Authors' survey based on data from Eurostat (2007-2011) and WEF (2007-2011)

A positive relationship exists between all innovation indices (GCI subindex-innovation and sophistication factor subindex, GCI $11^{\text {th }}$ pillar: business sophistication, and GCI $12^{\text {th }}$ pillar: innovation) and Internet usage, which refers to online banking (IntUSG1: use of online banking). A negative relationship exists between GCI subindex-innovation and sophistication factors and GCI $11^{\text {th }}$ pillar: business sophistication and Internet usage regarding finding employment via the Internet (IntUSG2: use of the Internet for finding employment). Based on the results, it could be concluded that Internet usage by individuals has a positive influence on a country's innovation activities. In other words, the second hypothesis (H2) of this paper has been confirmed. Our research confirms the similar results of other authors.

In today's information society, the Internet serves as the main source for the communication of individuals and organizations (Sharma \& Gupta, 2003). The main reasons are as follows: The Internet is cost-effective and faster than other communication media, improves learning, and encourages information and knowledge exchanges, and there are no time or space constraints (Akman \& Mishra, 2010;
Ramayah, 2010). However, Internet usage is not the same in developed and developing countries (Wallsten, 2005). Less developed countries do not encourage the development and usage of ICTs, which results in lower competitiveness and innovation activities. Therefore, looking for a job via the Internet is not common in developing countries. In addition, the lower quality of ICT infrastructures and higher prices for Internet access lead to the lower usage of Internet banking. Developed countries are trying to increase their competitiveness through new processes, products, and applications, which is the reason for ICT usage in the finance industry to offer new and unique services via the Internet for clients (Cho \& Park, 2012). The usage of ICT applications in financial business enhance innovation and increase the quality of financial services for clients.

\section{H3: The increase of eBusiness usage has a positive influence on innovation activities}

Table 5 presents the relationships between the individual independent variable eBusiness (eBUS) and the dependent variables GCI subindex-innovation and sophistication factor subindex, GCI $11^{\text {th }}$ pillar: business sophistication, and GCI $12^{\text {th }}$ pillar: innovation. The independent variable eBusiness is presented through three areas: eBUS1: CRM software usage, eBUS2: Selling goods or services over the Internet, and eBUS3: ordering via the Internet.

Table 5. Level of Statistical Significance of Independent Variable eBusiness (eBUS)

\begin{tabular}{|c|c|c|c|}
\hline \multirow[b]{2}{*}{$\begin{array}{l}\text { ICTs } \\
\text { variables }\end{array}$} & \multirow{2}{*}{$\begin{array}{c}\text { GCl subindex } \\
\text { Innovation and } \\
\text { Sophistication } \\
\text { Factors }\end{array}$} & \multicolumn{2}{|c|}{$\mathrm{GCl} 11^{\text {th }}$ and $12^{\text {th }}$ pillars } \\
\hline & & $\begin{array}{l}\text { Business } \\
\text { sophistication }\end{array}$ & Innovation \\
\hline \multicolumn{4}{|l|}{ eBUS1 } \\
\hline eBUS2 & $1 \%(+)$ & $1 \%(+)$ & $1 \%(+)$ \\
\hline eBUS3 & $5 \%(-)$ & & \\
\hline
\end{tabular}

Source: Authors' survey based on data from Eurostat (2007-2011) and WEF (2007-2011)

A positive relationship exists between all innovation indices (GCI subindex-innovation and sophistication factor subindex, GCI $11^{\text {th }}$ pillar: business sophistication, and GCI $12^{\text {th }}$ pillar: innovation) and the eBusiness indicator, which measures the active use of the Internet by enterprises (eBUS2: selling goods or services over the Internet). A negative relationship exists between GCI subindex-innovation and sophistication factor subindex and the eBusiness indicator related to placing orders over the Internet (eBUS3: ordering via the Internet). One of the reasons could be confidence 
when ordering via the Internet. This negative impact could also be a stimulation for ICT experts to introduce innovative and secure applications for ordering via the Internet. Based on these results, it can be concluded that eBusiness has a positive influence on a country's innovation activities. In other words, the third hypothesis (H3) of this paper has been confirmed.

According to Poon (2008), using new and unique software applications contributes to an innovative way of doing business, which increases companies' competitive advantage. Selling goods or services over the Internet and using customer relationship management innovate business processes and improve organizations' financial situations. Further improvement and the usage of the latest technology in eBusiness lead to a higher level of innovation activity in firms. eBusiness has several benefits, especially in sales, supply management, and interim processes of the organizations and leads to higher productivity and new and unique products and services (Zhu \& Kraemer, 2005).

\section{H4: The increase of eScience and technology transfer usage has a positive influence on innovation activities.}

Table 6 presents the relationship between the individual independent variable eScience and technology transfer (eSCNtechTR) and the dependent variables GCI subindex-innovation and sophistication factor subindex, GCI $11^{\text {th }}$ pillar: business sophistication, and GCI $12^{\text {th }}$ pillar: innovation.

Table 6. Level of Statistical Significance of Independent Variable eScience and Technology Transfer (eSCNtechTR)

\begin{tabular}{lccc} 
& \multicolumn{6}{|}{$\mathrm{GCl}$ subindex } & $\mathrm{GCl} 11^{\text {th }}$ and $12^{\text {th }}$ pillars \\
\cline { 2 - 4 } ICTs variables & $\begin{array}{l}\text { Innovation and } \\
\text { Sophistication } \\
\text { Factors }\end{array}$ & $\begin{array}{c}\text { Business } \\
\text { sophistication }\end{array}$ & Innovation \\
\hline eSCNtechTR1 & $1 \%(-)$ & $1 \%(-)$ & $1 \%(-)$ \\
\hline eSCNtechTR2 & & & \\
\hline eSCNtechTR3 & & $5 \%(+)$ \\
\hline eSCNtechTR4 & & $5 \%(+)$ \\
\hline eSCNtechTR5 & & \\
\hline eSCNtechTR6 & & \\
\hline
\end{tabular}

Source: Authors' survey based on data from Eurostat (2007-2011) and WEF (2007-2011)

The independent variable eScience and technology transfer is presented through six areas: eSCNtechTR1: high-technology import within EU27, eSCNtechTR2: high-technology import outside EU27, eSCNtechTR3: high-technology import in the world, eSCNtechTR4: high-technology export within EU27, eSCNtechTR5: high-technology export outside EU27, and eSCNtechTR6: high-technology export in the world.

A positive relationship exists between GCI $12^{\text {th }}$ pillar: innovation and two eScience and technology transfer indicators (eSCNtechTR4: high-technology export within EU27 and eSCNtechTR5: high-technology export outside EU27). A negative relationship exists between all innovation indices (GCI subindex-innovation and sophistication factor subindex, GCI $11^{\text {th }}$ pillar: business sophistication, and GCI $12^{\text {th }}$ pillar: innovation) and the eScience and technology transfer indicator eSCNtechTR2: high-technology import outside EU27. Based on the results, it can be concluded that eScience and technology transfer have a positive influence on a country's innovation activities. In other words, the fourth hypothesis (H4) of this paper has been confirmed.

Our research confirms the similar results of other authors. eScience and technology transfer refer to the exchange of knowledge, ideas, and information among scientific and research institutions and enterprises (Liu \& Jiang, 2001). In other words, technology transfer presents an exchange of skills, knowledge, and methods from the place they are developed to other places where they will be used (Beheshtinia et al., 2014). The development and usage of high technologies has a positive impact on competitiveness and business innovation (Rogers et al., 2001). Technology transfer is mostly used in trade between developing countries and developed ones. Thus, developed countries can benefit a lot from the import of high technology, such as by lowering risk and financial costs of research projects in science and technology (Li \& Wei, 2012).

\section{H5: The increase of eGovernment usage has a positive influ- ence on innovation activities.}

Table 7 presents the relationships between the individual independent variable eGovernment (eGOV) and the dependent variables GCI subindex-innovation and sophistication factor subindex, GCI $11^{\text {th }}$ pillar: business sophistication, and GCI $12^{\text {th }}$ pillar: innovation. The independent variable eGovernment is presented through two areas: eGOV1: using public administration sites to send forms and eGOV2: communication with public departments.

A positive relationship exists between the GCI $11^{\text {th }}$ pillar: business sophistication with the indicator measuring the active use of eGovernment by individuals (eGOV2: communication with public administration units). Based on the results, it could be concluded that eGovernment has a positive influence on a country's innovation activities. In other words, the fifth hypothesis (H5) of this paper has been confirmed. 
Table 7. Level of Statistical Significance of Independent Variable eGovernment (eGOV)

\begin{tabular}{|c|c|c|c|}
\hline \multirow[b]{2}{*}{$\begin{array}{l}\text { ICTs } \\
\text { variables }\end{array}$} & \multirow{2}{*}{$\begin{array}{c}\text { GCl subindex } \\
\text { Innovation and } \\
\text { Sophistication } \\
\text { Factors }\end{array}$} & \multicolumn{2}{|c|}{$\mathrm{GCl} 11^{\text {th }}$ and $12^{\text {th }}$ pillars } \\
\hline & & $\begin{array}{c}\text { Business } \\
\text { sophistication }\end{array}$ & Innovation \\
\hline \multicolumn{4}{|l|}{ eGOV1 } \\
\hline eGOV 2 & & $5 \%(+)$ & \\
\hline
\end{tabular}

Source: Authors' survey based on data from Eurostat (2007-2011) and WEF (2007-2011)

According to Irani, Love, and Jones (2008), eGovernment services are important for implementing innovative changes and new services in public institutions that lead to a higher quality of business processes and satisfied clients. Developed countries have made a significant effort in the development and usage of eGovernment services. One positive example is the transparent system of electronic voting, which was first used in Estonia (Randver, 2006). However, developing countries still lag behind because of the lower level of ICT development and their quality (Ndou, 2004). Therefore, the active usage of eGovernment, especially in the field of communication and access to the information, facilitates administrative activities within public and state institutions and improves the quality of their work.

\section{Conclusion}

\section{Summary of research}

ICTs are becoming increasingly important in various aspects of everyday life because of their accelerated development and implementation. In this paper, the main goal was to evaluate the impact of ICTs on innovation business activities in selected European countries. After the panel regression analysis was conducted, research results confirmed the impact of ICTs as a supporting factor for innovation activities. Research revealed a positive relationship between all innovation indices (GCI subindex-innovation and sophistication factor subindex, GCI $11^{\text {th }}$ pillar: business sophistication, and GCI $12^{\text {th }}$ pillar: innovation) and three independent variables (eLRN1: purchase of materials for e-learning; IntUSG1: use of online banking, and eBUS2: Internet purchase) regarding three different ICT areas (eLearning, eBusiness, and eGovernment). A positive relationship exists between GCI $11^{\text {th }}$ pillar: business sophistication and two independent variables (eLRN3: use of the Internet for education and training and eGOV2: communication with public departments). In the area of eScience and technology transfer, a positive relationship exists between
GCI $12^{\text {th }}$ pillar: business sophistication and two independent variables (eSCNtechTR4: high-technology export within EU27 and eSCNtechTR5: high-technology export outside EU27). It can be concluded that the impact of ICTs on innovation activities is the strongest in the areas of eLearning, Internet usage, and eBusiness as the most variables from these areas impacted GCI subindex-innovation and sophistication factor subindex, GCI $11^{\text {th }}$ pillar: business sophistication, and GCI $12^{\text {th }}$ pillar: innovation.

\section{Research contributions}

The presented research has both practical and theoretical contributions. Practical contributions stem from the fact that the results provide a framework for better understanding the issues associated with ICTs and their influence on innovation performance, which is relevant to both firms and policymakers at the national level. Better understanding of the role that ICTs play in innovation activity will help decision makers create more relevant and transparent policies and strategies, which could stimulate ICT usage and application. Actually, identifying different ICT areas and their impact on innovation activity may enable policymakers to define strategies and initiatives that will improve and boost innovation performance in a particular segment of socio-economic development.

Theoretical contributions of the research stem from the fact that the impact of ICT usage in society was estimated using the Global Competitiveness Framework as a proxy for the innovativeness in European countries, with a focus on the innovation and sophistication factor subindex, $11^{\text {th }}$ pillar: business sophistication, and $12^{\text {th }}$ pillar: innovation. Other researchers focused on narrower definitions of innovativeness, such as Yunis et al. (2012). However, our results are in line with their results in terms of the positive impact of ICT usage on innovativeness.

\section{Limitations and future research}

Limitations of the work come from four sources. First, the five-year time span could be considered too short for defining the impact of ICT usage on innovativeness. Second, the data used come from the two different sources (Eurostat and Global Competitiveness Index). Third, it is possible that the impact of ICT on innovation is not immediate and a time lag should have been taken into account. Fourth, in relation to the impact of ICTs to innovativeness, the nonlinear impact and possibility of feedback are missing from this analysis, especially taking into account that the ICTs are themselves also one of the most important innovations of contemporary societies. 
Future research could be extended in four directions. First, a broader group of countries could be taken into account for the analysis in order to assess the impact of ICT usage on least developed countries from Africa, Asia, and Latin America to determine if countries with the lowest level or infrastructural development are still able to overcome the digital divide and use ICTs to move ahead. Second, the time span for the future analysis should be extended to define the longer impact of
ICTs on innovativeness, because the growth of ICT usage since the 1990s has been exponential. Also, the time lag of ICT impact on innovativeness should be taken into account. Third, a different aggregate measurement of the innovativeness could be used in future research, such as the Summary Innovation Index (EC, 2011). Finally, future research should focus on methods that could capture nonlinear impact and the possibility of feedback as well, as previously mentioned.

\section{References}

1. Aguilera Enriquez, L., Cuevas-Vargas, H., \& Gonzalez Adame, M. (2015). The impact of information and communication technologies on the competitiveness: Evidence of manufacturing SMEs in Aguascalientes, Mexico. International Review of Management and Business Research, 4(3), 758-770.

2. Akman, I., \& Mishra, A. (2010). Gender, age and income differences in internet usage among employees in organizations. Computers in Human Behavior, 26(3), 482-490. http://dx.doi.org/10.1016/j.chb.2009.12.007

3. Anon Higon, D. (2011). The impact of ICT on innovation activities: Evidence for UK SMEs. International Small Business Journal, 30(6), 684-699. http://dx.doi.org/10.1177/0266242610374484

4. Arvanitis, S., Loukis, E., \& Diamantopoulou, V. (2013). The effect of soft ICT capital on innovation performance of Greek firms. Journal of Enterprise Information Management, 26(6), 679-701. http://dx.doi.org/10.1108/JEIM-07-2013-0048

5. Bell, J. (2007). E-learning: Your flexible development friend? Development and Learning in Organizations, 21(6), 7-9. http://dx.doi. org/10.1108/14777280710828558

6. Berman, S. J., \& Hagan, J. (2006). How technology-driven business strategy can spur innovation and growth. Strategy \& Leadership, 34(2), 28-34. http://dx.doi.org/10.1108/10878570610700848

7. Blackman, C. (2004). Stumbling along or grave new world? Towards Europe's information society. Foresight, 6(5), 261-270. http:// dx.doi.org/10.1108/14636680410562963

8. Bocconi, S., Kampylis, P., \& Punie, Y. (2013). Framing ICT-enabled innovation for learning: the case of one-to-one learning initiatives in Europe. European Journal of Education, Research, Development and Policy, 48(1), 113-130. http://dx.doi.org/10.1111/ejed.12021

9. Campisi, D., De Nicola, A., Farhadi, M., \& Mancuso, P. (2013). Discovering the impact of ICT, FDI and human capital on GDP: A cross-sectional analysis. International Journal of Engineering Business Management, 5, 1-10. http://dx.doi.org/10.5772/56922

10. Carter, L., \& Belanger, F. (2005). The utilization of eGovernment services: Citizen trust, innovation and acceptance factors. Information Systems Journal, 15, 5-25. http://dx.doi.org/10.1111/j.1365-2575.2005.00183.x

11. Chatzoglou, P. D., \& Vraimaki, E. (2010). Investigating internet usage as innovation adoption: a quantitative study. Journal of Information, Communication and Ethics in Society, 8(4), 338-363. http://dx.doi.org/10.1108/14779961011093345

12. Cho, D. H., \& Park, J. H. (2012). Examining the performance of internet-based business models: Evidence from the internet banks. International Journal of $u$ - and e-Service, Science and Technology, 5(1), 51-61.

13. Cross, J. (2004). An informal history of eLearning. On the Horizon, 12(3), 103-110. http://dx.doi.org/10.1108/10748120410555340

14. Damanpour, F. (2001). eBusiness, eCommerce evolution: Perspective and strategy. Managerial Finance, 27, 16-33. http://dx.doi. org/10.1108/03074350110767268

15. Eurostat. (2015). European Commission database. Retrieved from http://ec.europa.eu/eurostat

16. European Commission. (2010, November). Europe's digital competitiveness report. Retrieved from file:///C:/Users/jzoroja/ Downloads/Nolume1Mainreport.pdf

17. European Commission. (2011). European Innovation Scoreboard (EIS) 2010. Retrieved from http://www.proinno-europe.eu/metrics

18. Haseeb, H. M. (2015). The role of ICT management to achieve organizational innovation. The International Journal of Organizational Innovation, 7(4), 48-57.

19. Hasim, M. S., \& Salman, A. (2010). Factors affecting sustainability of internet usage among youth. The Electronic Library, 28(2), 300-313. http://dx.doi.org/10.1108/02640471011033657

20. Haythornthwaite, C., \& Wellman, B. (2002). The internet in everyday life: an introduction. In B. Wellman \& C. Haythornthwaite (Eds.), The internet in everyday life (pp. 3-44). Malden, MA: Blackwell. http://dx.doi.org/10.1002/9780470774298.ch

21. Hjalager, A. M. (2010). A review of innovation research in tourism. Tourism Management, 31, 1-12. http://dx.doi.org/10.1016/j. tourman.2009.08.012

22. Irani,Z., Love, P.E., \& Jones, S. (2008). Learning lessons from evaluating eGovernment: Reflective case experiences that support transformational government. The Journal of Strategic Information Systems, 17(2), 155-164. http://dx.doi.org/10.1016/j.jsis.2007.12.005

23. Jones, P., Beynon-Davies, P., \& Muir, E. (2003). E-business barriers to growth within the SME sector. Journal of Systems and Information Technology, 7(1/2), 1-25. http://dx.doi.org/10.1108/13287260380000771

24. Khalil, O. E. M. (2011). E-Government readiness: Does national culture matter? Government Information Quarterly, 28(3), 388-399. http://dx.doi.org/10.1016/j.giq.2010.06.011 
25. Kleis, L., Chwelos, P., Ramirez, R. V., \& Cockburn, I. (2012). Information technology and intangible output: The impact of IT investment on innovation productivity. Information Systems Research, 23(1), 42-59. http://dx.doi.org/10.1287/isre.1100.0338

26. Koellinger, P. (2008). The relationship between technology, innovation, and firm performance-Empirical evidence from E-Business in Europe. Research Policy 37, 1317-1328. http://dx.doi.org/10.1016/j.respol.2008.04.024

27. Landry, R., Amara, N., Cloutier, J. S., \& Halilem, N. (2013). Technology transfer organizations: Services and business models. Technovation, 33, 431-449. http://dx.doi.org/10.1016/j.technovation.2013.09.008

28. Li, W., \& Wei, Y. (2012). Technology transfer, adaptation and assimilation and indigenous invention patent output: Evidence from Chinese high-tech industries. Procedia engineering, 29, 1392-1398. http://dx.doi.org/10.1016/j.proeng.2012.01.146

29. Liu, H., \& Jiang, Y. (2001). Technology transfer from higher education institutions to industry in China: Nature and implications. Technovation, 21(3), 175-188. http://dx.doi.org/10.1016/S0166-4972(00)00045-6

30. Morgan, A., Colebourne, D., \& Thomas, B. (2006). The development of ICT advisors for SME businesses: An innovative approach. Technovation, 26(8), 980-987. http://dx.doi.org/10.1016/j.technovation.2005.09.001

31. Ndou, V. (2004). E-Government for developing countries: Opportunities and challenges. The Electronic Journal on Information Systems in Developing Countries, 18(1), 1-24.

32. Ongori, H., \& Migiro, S. O. (2010). Information and communication technology adoption: A literature review. Journal of Chinese Entrepreneurship, 2(1), 93-104. http://dx.doi.org/10.1108/17561391011019041

33. Pavel, A. P., Fruth, A., \& Neacsu, M. N. (2015). ICT and E-Learning-Catalysts for innovation and quality in higher education. Procedia Economics and Finance, 23, 704-711. http://dx.doi.org/10.1016/S2212-5671(15)00409-8

34. Pejić Bach, M. (2014). Exploring information and communications technology adoption in enterprises and its impact on innovation performance of European countries. Ekonomický časopis, 62(4), 335-362.

35. Pena Seixas, S. I. F. B., Bostock, J., \& Eleftheriou, M. (2012). Promoting sustainable aquaculture. Management of Environmental Quality: An International Journal, 23(4), 434-450. http://dx.doi.org/10.1108/14777831211232245

36. Poon, S. (2008). Future of small business E-Commerce. In A. Becker (Ed.), Electronic commerce concepts, methodologies, tools and applications, IV, 1466 - 1473, Information Science Reference. http://dx.doi.org/10.4018/978-1-59904-943-4.ch166

37. Puzova, K., \& Maresova, P. (2014).Czech Republic's competitiveness in ICT market. Procedia-Social and Behavioral Sciences, 109, 880-885. http://dx.doi.org/10.1016/j.sbspro.2013.12.558

38. Ramayah, T. (2010). Personal web usage and work inefficiency. Business Strategy Series, 11(5), 295-301. http://dx.doi. org/10.1108/17515631011080704

39. Randver, R. (Ed.). (2006). Information technology in public administration of Estonia. Yearbook 2005. Tallinn: Ministry of Economic Affairs and Communications. Retrieved from http://www.inst-informatica.pt/servicos/informacao-e-documentacao/biblioteca-digital/areas-aplicacionais/administracao-publica-electronica/2006/INFORMATIONTECHNOLOGYINPUBLICADMINISTRATIONOFESTONIAYEARBOOK2005.pdf

40. Rogers, E. M., Takegami, S., \& Yin, J. (2001). Lessons learned about technology transfer. Technovation, 21(4), 253-261. http://dx.doi. org/10.1016/S0166-4972(00)00039-0

41. Santos, D. F. L., Basso, L. C., \& Kimura, H. (2014). The influence of innovation on firm performance in Brazil. Journal of Business Research, 67(4), 527-535. http://dx.doi.org/10.1016/j.jbusres.2013.11.009

42. Sexton, M., \& Barrett, P. (2004). The role of technology transfer in innovation within small construction firms. Engineering, Construction and Architectural Management, 11(5), 342-348. http://dx.doi.org/10.1108/09699980410558539

43. Sharma, S. K., \& Gupta,J.T.N.(2003). Improving workers' productivity and reducing internet abuse. The Journal of Computer Information Systems, 44(2), 74-78.

44. Singh, P. K. (2012). Management of business process can help an organization achieve competitive advantage. International Management Review, 8(2), 19-26.

45. Varis, M., \& Littunen, H. (2010). Types of innovation, sources of information and performance in entrepreneurial SMEs. European Journal of Innovation Management, 13(2), 128-154. http://dx.doi.org/10.1108/14601061011040221

46. Vehovar, V., \& Lesjak, D. (2007). Characteristics and impacts of ICT investments: Perceptions among managers. Industrial Management and Data Systems, 107(4), 537-550. http://dx.doi.org/10.1108/02635570710740689

47. Vu, K. M. (2011). ICT as a source of economic growth in the information age: Empirical evidence from the 1996-2005 period. Telecommunications Policy, 35(4), 357-372. http://dx.doi.org/10.1016/j.telpol.2011.02.008

48. Wallsten, S. (2005). Regulation and internet use in developing countries. Economic Development and Cultural Change, 53(2), $501-523$. http://dx.doi.org/10.1086/425376

49. Wan, Z., Wang, Y., \& Haggerty, N. (2008). Why people benefit from e-learning differently: The effects of psychological processes on e-learning outcomes. Information and Management, 45(8), 513-521. http://dx.doi.org/10.1016/j.im.2008.08.003

50. World Economic Forum. (2007-2015). The global competitiveness report. Retrieved from http://www.weforum.org/

51. World Economic Forum. (2011-2015). The global information technology report. Retrieved from http://www.weforum.org/

52. Yunis,M.M., Koong,K.S., Liu,L.C.,Kwan, R., \& Tsang,P.(2012).ICT maturity as a driver to global competitiveness:Anational level analysis. International Journal of Accounting and Information Management, 20, 255-281. http://dx.doi.org/10.1108/18347641211245137

53. Zhang, D., \& Nunamaker,J. (2003). Powering E-Learning in the new millennium: An overview of E-Learning and enabling technology. Information Systems Frontier, 5(2), 207-218. http://dx.doi.org/10.1023/A:1022609809036 
54. Zhu, K., \& Kraemer, K. L. (2005). Post-adoption variations in usage and value of E-Business by organizations: Cross-country evidence from the retail industry. Information Systems Research, 16(1), 61-84. http://dx.doi.org/10.1287/isre.1050.0045

55. Zoroja, J. (2011). Internet, e-Commerce and e-Government: Measuring the gap between European developed and post-communist countries. Interdisciplinary Description of Complex Systems, 9(2), 119-133.

56. Zoroja, J. (2015). Fostering competitiveness in European countries with ICT: GCI agenda. International Journal of Engineering Business Management, 7, 1-8. http://dx.doi.org/10.5772/60122

\section{Author}

Jovana Zoroja, Ph.D., is an assistant professor at the Faculty of Economics and Business, University of Zagreb, Department of Informatics, where she received her Ph.D. with the dissertation thesis "Influence of the Information and Communication Technologies on the Competitiveness of the European Union Countries." She was educated at the LSE-Summer School in London in the field of business development and ICTS innovation (2008). Her main research interests are information and communication technology, e-learning, simulation games and simulation modelling. She has published several scientific papers in international and national journals and participated in many scientific conferences. She is actively engaged in a number of scientific projects.

\section{Vpliv IKT na inovacijske dejavnosti: Indikacija za izbrane evropske države}

\section{Izvleček}

Razvoj in uporaba informacijskih in komunikacijskih tehnologij (IKT) sta se povečala predvsem v zadnjih dveh desetletjih. $\mathrm{V}$ istem obdobju se kaže tudi velik potencial za izboljšanje poslovnih procesov, za pospeševanje in spodbujanje inovacij, torej za povečanje konkurenčnosti. Inovacijske dejavnosti so pomemben dejavnik družbenih in ekonomskih sprememb ter povečanja konkurenčnih prednosti na nacionalni in podjetniški ravni. V tem članku se osredotočamo na vlogo, ki jo imajo IKT v inovacijski uspešnosti izbranih evropskih držav. Pri raziskavi so bili uporabljeni podatki iz Eurostata in Global competitiveness Indexa (2007-2011) ter panelna regresijska analiza, rezultati pa kažejo, da imajo IKT pomemben vpliv na poslovne inovacijske dejavnosti.

Ključne besede: informacijska in komunikacijska tehnologija, inovacija, poslovna razvitost, konkurenčnost, evropske države, regresijska analiza 